Erratum

\title{
Erratum to: An Experimental Study on Bending Performance of Hybrid Forming Composite Beam
}

\author{
Sung-Bae Kim', Seong-Hyun $\mathrm{Cho}^{2}$, Young-Han $\mathrm{Choi}^{2}$, and Sang-Seup Kim ${ }^{3, *}$ \\ ${ }^{1}$ Ph.D., The Naeun Structural Engineering, Seoul, 07205, Korea \\ ${ }^{2}$ Graduate Student, Department of Architectural Engineering, KOREATECH., Cheonan, 31253, Korea \\ ${ }^{3}$ Professor, School of Design \& Architectural Engineering, KOREATECH., Cheonan, 31253, Korea
}

() KSSC and Springer 2018

Erratum to: International Journal of Steel Structures 17(4): 1641-1651 (2017)

DOI 10.1007/s13296-017-1228-3

Keywords:

Keywords are missing in the original version of the article. The Keywords should be as following:

Keywords: High-Strength Steel, Hybrid Forming Composite Beam, Bending Performance

published online March 31, 2018

(C) KSSC and Springer 2018

\footnotetext{
*Corresponding author

Tel: +82-41-560-1330, Fax: +82-41-560-1224

E-mail:kimss@koreatech.ac.kr
} 